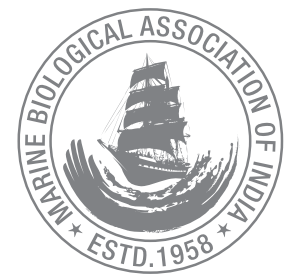

\title{
Report of Xanthid crab Lophozozymous incisus (H. Mille Edwards, 1834) from the gut of Humpback red snapper Lutjanus gibbus
}

\author{
Rekha J. Nair*, Lakshmi Pillai, P.K. Seetha and S.Dinesh Kumar \\ Central Marine Fisheries Research Institute, Ernakulam North P.O, Kochi 682 018, Kerala, India. \\ *Correspondence e-mail: rekhacmfri@gmail.com
}

Received: 09 Oct 2012, Accepted: 15 May 2013, Published: 30 May 2013 Short Communication

\begin{abstract}
Two specimens of Lophozozymous incisus were collected from the gut of Humpback red snapper Lutjanus gibbus caught in hooks and lines off Cochin. L. incisus belongs to Family Xanthidae, the largest family of brachyuran crabs. The crab has only been reported from Angrias Bank, Maharashtra and Orissa coast. This is the first report from the southern waters.
\end{abstract}

Keywords: Lophozozymous incisus, xanthid crab, Lutjanus gibbus, pebble crabs, gut contents.

\section{Introduction}

Xanthid crabs (Family Xanthidae) commonly called the pebble crabs form the largest family of brachyuran crabs and are distributed widely in the Indo-Pacific region. Most of them are beautifully coloured and are found to inhabit diverse habitats from coral reefs to sandy and rocky bottoms. Since most are small in size, they are not of much economic value. They are often brightly coloured and are poisonous, containing toxins which are not destroyed by cooking and for which no antidote is known. The toxins are similar to the tetrodotoxin and saxitoxin produced by puffer fish, and may be produced by bacteria in the genus Vibrio living in symbiosis with the crabs, mostly V. alginolyticus and V. parahaemolyticus ( $\mathrm{Ng}$ and Chia 1997).
Type locality of the species is Australasia reported by Haswell (1882). In India the crab has been recorded earlier only from Angrias Bank, Maharashtra at 15 fathoms depth and from Orissa coast at 15-35 fathoms (Alcock, 1898). However, there are no records of its distribution in the southern waters.

\section{Material and methods}

Two specimens were collected from the gut of two Lutjanus gibbus fishes sampled from hooks and line landings off Cochin during December 2011. The fishes were of lengths (TL $30 \mathrm{~cm}$, $36.5 \mathrm{~cm}$ ) and weights $340 \mathrm{~g}$ and $600 \mathrm{~g}$ respectively. The fishes were immature male and female respectively. The xanthid specimen (Acc. No.E.D 5.8.7.1) examined is deposited in the National Marine Biodiversity Referral Museum of the Central Marine Fisheries Research Institute, Kochi, India.

Lophozozymous incisus (H. Milne Edwards 1834)

Sex : Male

Family : Xanthidae Macleay 1838

Subfamily : Zosiminae, Alcock 1898

Species : Lophozozymous incisus (H. Milne Edwards 1834)

\section{Synonyms}

Xantho incisus H. Milne Edwards 1834: 394;

Xantho superbus Dana 1852:167, pl.8, figs. 5a, b 


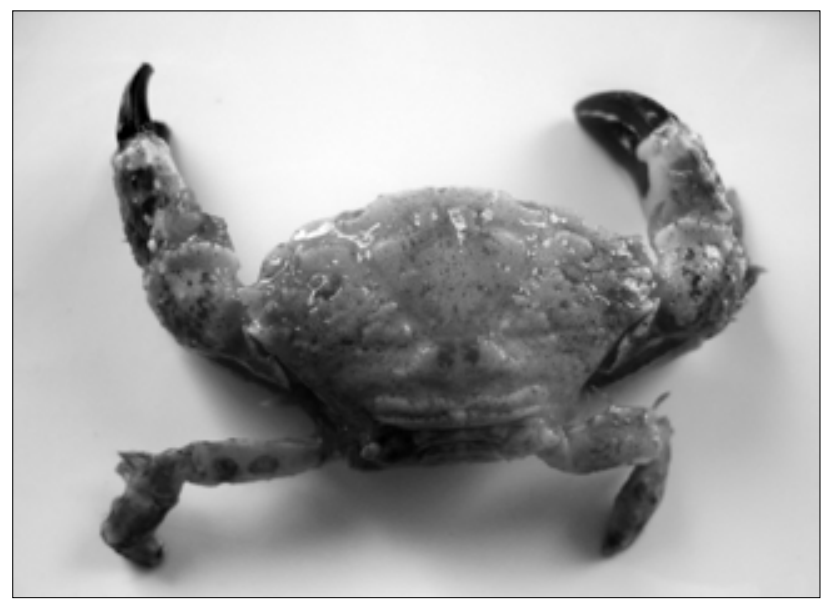

Fig.1 Dorsal view of Lophozozymus incisus

Lophozozymus incisus Haswell 1882:58; De Man 1887: 268, pl.10, fig. 1; Alcock 1898: 107; Lenz 1901: 461; Rathbun 1906: 846; Sakai 1939: 452, pl. 88, fig. 2; Buitendijk 1960: 295; Edmondson 1962: 232, figs. 4a, 5a.

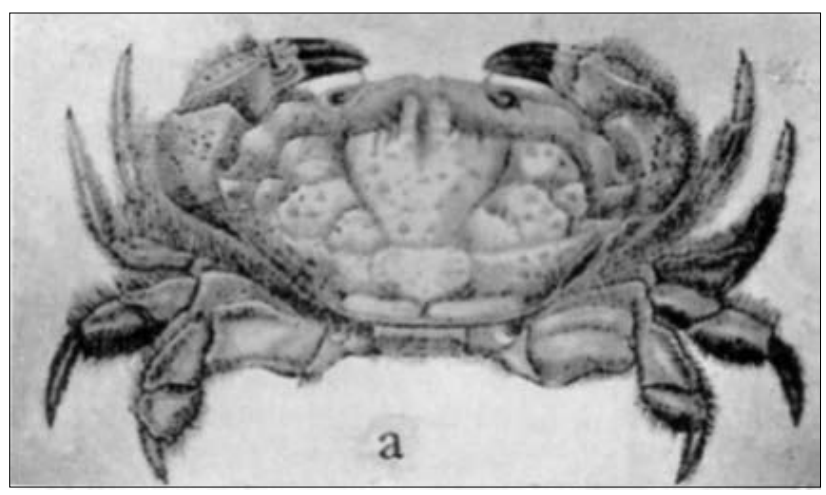

Fig.2 Lophozozymus incius from Hawaii Source: Edmondson, 1962.

\section{Description:}

Carapace width : $26.9 \mathrm{~mm}$

Carapace length : $17.5 \mathrm{~mm}$

Cheliped length : $26.4 \mathrm{~mm}$

Abdomen length : $8.1 \mathrm{~mm}$

Carapace broad and slightly convex. Surface of carapace rough but well defined. Frontal portion of the antero-lateral border of carapace divided into four lobes, first two are confluent and fused with the orbit and other two are pointed and strongly keeled. The anterior lobes of antero-lateral border do not extend beyond the level of the exorbital angles. Orbital border is smooth. Gastric and hepatic regions of carapace have well defined lobules which are uneven or dented. Lobules are separated by grooves which have hair. Chelipeds equal in size with pointed fingers. Length of chelipeds is equal to the width of the carapace. Upper border of arm, palm and dactylus crested. Outer surface of wrist and palm covered with large granules or horizontal rows of small tubercles. Ambulatory legs are narrow. Furrows on the carapace, chelipeds and walking legs have hair. The $3^{\text {rd }}$ to $5^{\text {th }}$ abdominal terga are fused together without obliteration of sutures.

Colour: Ivory white with orange red patches on the carapace and appendages. Fingersare dark brown/black.

Distribution: The species has been reported from Japan, Taiwan, Indonesia, Australia, Hawaiian Islands, Sri Lanka, New Zealand, New Guinea, Orissa and Maharashtra.

\section{Remarks}

This is the first record of the species after Alcock (1898) reported its occurrence from Angrias Bank and also the first record from the gut of a fish (Lutjanus gibbus). Although two specimens of the species were obtained from the fish gut, only one was intact, the other presumably had undergone partial digestion with one leg missing. The presence of the other leg helped in the identification of the crab. Since closely related species Lophosozymous pictor is reported to be highly poisonous, further studies should be taken up on the stomach contents of Lutjanus gibbus.

\section{Acknowledgements}

The authors are thankful to the Director, Central Marine Fisheries Research Institute and to the Heads of Demersal and Crustacean Fisheries Divisions for their constant encouragement and support extended to the study.

\section{References}

Alcock, A. 1898. Material for carcinological fauna of India. No.1 The Brachyura Oxyrhyncha. J.Asiat. Soc. Bengal, LXIV(II), (2):1-456.

Haswell, W. A. 1882.Catalogue of the Australian stalk and sessile eyed crustacean. The Australian Museum, Sydney: 1-368.

$\mathrm{Ng}$, P. K. L and Chia. D. B. G. 1997. Lophozozymus erinnyes, a new species of poisonous crab from Australia, with notes on L. pictor (Fabricius, 1798), L. incisus (H. Milne Edwards, 1834) and L. edwardsi (Odhner, 1925) (Crustacea: Decapoda: Brachyura: Xanthidae). Raffles Bull. Zool., 45(2): 419-443. 